\title{
Effect of Flaxseed Flour and Xanthan Gum on Gluten-Free Cake Properties
}

\author{
Wen Chieh Sung*, Pei-Shan Chai \\ Department of Food Science, National Taiwan Ocean University, Keelung, Taiwan \\ *Corresponding author: sungwill@mail.ntou.edu.tw
}

\begin{abstract}
The aim of this study was to evaluate the influence of incorporation of xanthan gum and flaxseed flour on physicochemical, antioxidant properties and qualities of gluten-free layer cake replaced rice flour up to $60 \%$. The incorporation of flaxseed flour increased crude protein, crude fat, ash and $\alpha$-linolenic acid (increase up to $14.67 \%$ of total fatty acid with the replacement of $60 \%$ rice flour). Replacement of rice flour with flaxseed flour can mitigate the rate of hardness increase in gluten-free layer cakes. Significantly higher total phenolics content (114\% increase), 1,1-diphenyl-2-picrylhydrazyl hydrate (DPPH) radical scavenging activity (124\% increase) and reducing power (213\% increase) was observed in the addition of flaxseed flour comparing to rice flour layer cake. $60 \%$ Flaxseed flour supplemented cake resulted in higher batter viscosity but lower crust and crumb white index, batter density, center height, volume index and symmetry index of gluten-free layer cake. Sensory evaluation showed rice flour gluten-free layer cake with $0.8 \%$ xanthan gum addition had higher aroma, texture, flavor and overall acceptability followed by $40 \%$ flaxseed flour replaced cake. Incorporation of $40 \%$ flaxseed flour results in better characteristics gluten-free layer cakes and it is feasible for gluten-free cake application.
\end{abstract}

Keywords: Gluten-free cake, flaxseed flour, rice flour, xanthan gum

Cite This Article: Wen Chieh Sung and Pei-Shan Chai, "Effect of Flaxseed Flour and Xanthan Gum on Gluten-Free Cake Properties." Journal of Food and Nutrition Research, vol. 5, no. 10 (2017): 717-728. doi: $10.12691 /$ jnr-5-10-1.

\section{Introduction}

Celiac disease is diagnosed as people allergy to the consumption of prolamins fraction of gluten specific in wheat, rye and barley [1]. It is a genetically predisposed persons as a consequence of autoimmune disorder affecting the gastrointestinal system resulting in inflammation and damage to the lining of the small intestine [2]. Celiac disease reduces absorption of nutrients iron, calcium, vitamins $\mathrm{A}, \mathrm{D}, \mathrm{E}, \mathrm{K}$ and folate for these group consumers, who around $1 \%$ of the population in USA and Europe [3].

Wheat storage protein, glutelins and prolamins, after addition of water can be knead and formed viscoelastic cohesive dough. Wheat gluten is responsible for the cohesive and viscoelastic flow properties of dough. Such rheological properties give the dough gas-holding capacity during fermentation or with the addition of baking power. Therefore, wheat gluten provides a porous, spongy product with an elastic crumb after baking [4]. Because the prolamin fractions of wheat, barley or rye will cause the celiac disease [5], it is often eliminated by a change of diet to rice, corn, millet, sorghum or legume flours $[6,7,8]$. Hydrocolloids such as xanthan gum can improve the gas retention, dough development and work as emulsifiers through an increase in viscosity for gluten-free breads [5]. Rice flour has been used as main cereal flour for replacing wheat flour $[9,10,11]$ for celiac disease consumers.
Although gluten-free products on the market most made from rice flour [2], the products lead to low protein and fiber content in comparison with wheat products [6].

Flaxseed hull contains water-extractable dietary fiber which consists of acidic rhamnose-containing polysaccharides and arabinoxylans mucilage [12]. The lignin of flaxseed hull composed of 1 secoisolariciresinol diglucoside (SDG) which is phenolics. SDG of flaxseed lignin could convert into enterolactone and enterodiol which are estrogen like compounds and they are also able to inhibit the development of non-hormone-related colon cancers [13]. Xanthan gum and flaxseed hull differ in hydration properties, solubility and viscosity. There is no information about the individual xanthan gum and flaxseed flour effect on the quality parameters of glutenfree layer cakes. Therefore, the objective of this study was to investigate the potential of different ratio of flaxseed flour and rice flour or xanthan gum on the nutritional characteristics, processing parameter and quality of gluten-free layer cakes.

\section{Materials and Methods}

\subsection{Materials}

Japonica rice flour, fresh milk, sucrose fresh whole eggs, flaxseed flour, and double-action baking powder were purchased from a local market. Cake flour used in this study was purchased from the Cha Hwa corporation 
(Taichung, Taiwan). Kjeldahl catalyst tablets, sodium hydroxyl, boric acid, sulfuric acid, methyl red 1,1diphenyl-2-picrylhydrazyl, ferrous chloride 4-hydrate, and ferrozine (3-(2-pyridyl)-5,6-bis(4-phenylfulfonic acid)1,2,4-triazine were purchased from Panreac Appli Chem (Gatersleben, Saxony-Anhalt, Germany). All reagents used were of analytical grade. Acetone, methanol, ethanol, trichloracetic acid, and acetic acid were purchased from Sigma Aldrich (St. Louis Missouri, USA). Monobasic sodium phosphate dibasic sodium phosphate, methyl red, and sulfuric acid were purchased from Merck (Whitehouse station, NJ, USA). Ethyl ether was purchased from Nihon Shiyaku industries (Taiwan, R.O.C.).

\subsection{Gluten-Free Layer Cake Preparation}

A single-bowl mixing procedure was used for making gluten-free layer cakes according to Gularte et al. [14]. The basic recipe gluten free layer cake and flaxseed flour replaced formulations up to $60 \%$ rice flour are shown in Table 1. Gluten-free layer cake also added with $0.2-1.0 \%$ of xanthan gum. All ingredients were mixed for $1 \mathrm{~min}$ at speed 4, and $9 \mathrm{~min}$ at speed 6 using a Kitchen-Aid professional mixer (Kitchen Aid, St. Joseph, Michigan, USA). Cake batter (180 g) was placed into rectangular $(135 \mathrm{~mm} \times 70 \mathrm{~mm} \times 60 \mathrm{~mm})$, metallic, oil coated pans (650 $\mathrm{ml}$ of capacity), and was baked in an electric oven (Tabletop oven, Chuan Chiu Food Machine Co. Ltd., Guishan, Taoyuan County, Taiwan) for $15 \mathrm{~min}$ at $180^{\circ} \mathrm{C}$. After baking, the cakes were removed from the pans, left at room temperature for $1 \mathrm{~h}$ to cool down, and put into plastic pouches to prevent drying. Three different replications for each cake recipe were made in different days. Three cakes from the same batter were used for physical measurements that were performed on the same day after baking. One cake from each set was freeze dried for further determination of antioxidant assays. After cooling down, cake samples were inoculated pack in sterile LDPE pouches and kept in refrigerator $\left(4-7^{\circ} \mathrm{C}\right)$ and room temperature $\left(25^{\circ} \mathrm{C}\right)$ for 6 days. The cake samples were withdrawn at regular intervals for mold appearance evaluation.

\subsection{Batter Measurements}

Batter density was measured using an Electronic scale (Model NWTH-2K, Yuheng Weighing Equipment Co. Ltd., New Taipei City, Taiwan), which is a cup that consisted of a $20 \mathrm{ml}$ cylindrical container and a cover with a hole for removing excess of liquid [15]. The cup is initially weight empty for calibration and then after filling with the batter. Density was calculated by dividing the weight and the volume. Each formulation was measured three times. The viscosity of the cake batter was monitored at $25^{\circ} \mathrm{C}$ by using Brookfield digital viscometer (Model DV-II+, Engineering Labs., Inc., Middleboro, MA, USA) equipped with a SCS-34 spindle head at the spindle rotational speed of $3 \mathrm{rpm}$. The reading of the viscometer output started 2 min after the experiment onset.

\subsection{Cake Characteristics}

The volume, symmetry and uniformity were determined by using a plastic measuring template to calculate volume, contour and symmetry indices according to AACC method 10-91 [16]. Cakes were sliced in half, and the interior of the cake was placed against the template. Volume index was calculated by adding the center height of the cake with the points halfway between the center and outer edges.

\subsection{Determination of Cake Crust and Crumb Color, Water Activity, Texture Profile Analysis}

The color of the cake samples were examined with a spectrocolorimeter (TC-1800 MK II, Tokyo, Japan) using L (lightness), a (redness/greenness) and b (yellowness/ blueness) color scale according to the method of Cruz-Romero et al. [17]. Both a white tile and a black cup were examined before the test to standardize the spectrocolorimeter. The color of the cake samples was recorded after taking three measurements for each sample, and triplicate determinations were recorded for each treatment. The color difference

$$
\Delta \mathrm{E}=\left[(\Delta \mathrm{L})^{2}+(\Delta \mathrm{a})^{2}+(\Delta \mathrm{b})^{2}\right]^{1 / 2}
$$

where

$$
\begin{aligned}
& \Delta \mathrm{L}=\mathrm{L}_{\text {sample }}-\mathrm{L}_{\text {control }} \\
& \Delta \mathrm{a}=\mathrm{a}_{\text {sample }}-\mathrm{a}_{\text {control }} \\
& \Delta \mathrm{b}=\mathrm{b}_{\text {sample }}-\mathrm{b}_{\text {control }}
\end{aligned}
$$

Water activity of the cake crumb and crust were determined using a Novasina Thermoconstanter RTD 33

\begin{tabular}{|c|c|c|c|c|c|c|}
\hline Formulation $(\mathrm{g})$ & $\mathrm{C}$ & F20 & F40 & F60 & $\mathrm{X}$ & WF \\
\hline Rice flour & 100 & 80 & 60 & 40 & 100 & - \\
\hline Flaxseed flour & - & 20 & 40 & 60 & - & - \\
\hline Wheat flour & - & - & - & - & - & 100 \\
\hline Xanthan gum & - & - & - & - & 0.8 & - \\
\hline Milk & 75 & 75 & 75 & 75 & 75 & 75 \\
\hline Eggs & 62.5 & 62.5 & 62.5 & 62.5 & 62.5 & 62.5 \\
\hline Sunflower oil & 37.5 & 37.5 & 37.5 & 37.5 & 37.5 & 37.5 \\
\hline Sugar & 112.5 & 112.5 & 112.5 & 112.5 & 112.5 & 112.5 \\
\hline Baking powder & 3.7 & 3.7 & 3.7 & 3.7 & 3.7 & 3.7 \\
\hline
\end{tabular}
TH-1 avumeter (Novasina Co. Ltd., Pfaffikon, Switzerland) as described by Mathlouthi [18].

Table 1. Formulation of gluten-free cake

C: control gluten-free cake; F20: gluten-free cake supplemented with $20 \%$ of flaxseed flour; F40: gluten-free cake supplemented with $40 \%$ of flaxseed flour; F60: gluten-free cake supplemented with $60 \%$ of flaxseed flour; X: gluten-free cake supplemented with $0.8 \%$ of xanthan gum; WF: cake supplemented with $100 \%$ of wheat flour. 
Internal cake crumb was sliced into $30 \times 30 \times 30 \mathrm{~mm}$ samples and sealed in $1 \mathrm{~kg}$ polyethylene $(\mathrm{PE})$ bags after cooling and held at room temperature $\left(25^{\circ} \mathrm{C}\right)$ for further testing. Texture Profile Analysis (TPA) of cakes was tested with the TA.XT2 Texture Analyzer (Stable Micro Systems Co., Ltd., Haslemere, England) according the methods of Gularte et al. ${ }^{[8]}$. An aluminum cylindrical probe $(\mathrm{P} / 25 \mathrm{~A}$ probe, $25-\mathrm{mm}$ diameter) was used in a double compression test (texture profile analysis; TPA) with a compression up to $50 \%$ depth, at $2 \mathrm{~mm} / \mathrm{s}$ speed test, and 30s delay between first and second compression. Hardness $(\mathrm{N})$, springiness, cohesiveness, resilience was calculated from the TPA graph [8].

\subsection{Composition of Gluten-Free Layer Cake}

The proximate chemical composition of layer cake was determined according to the Association of Official Analytical Chemists method [19]. The moisture content of sample was conducted following AOAC procedure 984.25 by using oven drying at $105^{\circ} \mathrm{C}$ for $24 \mathrm{~h}$. Total ash was measured by burning the sample at $530^{\circ} \mathrm{C}$ for $24 \mathrm{~h}$. Lipid content of sample was determined using ether extraction method [19]. Crude protein $(\mathrm{N} \times 6.25)$ was measured using Kjeldahl method 955.04. Crude carbohydrate was obtained by 100 (moisture + crude protein + lipid content + total ash).

\subsection{Fatty Acid Analyses}

Lipid extraction was determined by homogenizing $15 \mathrm{~g}$ cake samples with $150 \mathrm{ml}$ chloroform-methanol mixture $(2: 1 ; \mathrm{v} / \mathrm{v})$ containing $0.2 \%$ butylated hydroxytoluene (BHA) as antioxidant. Total lipid content was measured gravimetrically after lipid extraction. The homogenization is carried out in an Oster 16-speed blender (Boca Raton, Florida, USA). After lipid extraction, $0.1 \mathrm{~g}$ of extracted lipids were spiked with $0.5 \mathrm{mg} / \mathrm{ml} \mathrm{C} 13: 0$ (Nu-Chel, Elysian, MI, USA) $1 \mathrm{ml}$ to monitor the extent of trans esterification as an internal standard.

Fatty acids were esterified into methyl esters according to AOAC [19]. Fatty acids were esterified into methyl esters and identification was carried out on a gas-chromatograph (HP-88). Fatty acid methyl esters was isolated and identified using a GC equip with a HP-88 fused slica capillary colume (100 $\mathrm{m} \times 0.25 \mathrm{~mm}$ internal diameter, $0.2 \mathrm{~mm}$ film thickness), temperature program was held at $140^{\circ} \mathrm{C}$ for $5 \mathrm{~min}$ and then raised the temperature from $140^{\circ} \mathrm{C}$ to $240^{\circ} \mathrm{C}$ at $4{ }^{\circ} \mathrm{C} / \mathrm{min}$, and held for $30 \mathrm{~min}$; injector and detector at $250^{\circ} \mathrm{C}$ (split ratio 50:1). Carrier gas was nitrogen at a constant flow 3.0 $\mathrm{ml} / \mathrm{min}$. Fatty acids were identified relative to known external standards and the resulting peak areas, corrected by the theoretical relative FID response factors. Each of the fatty acids was identified relative to known external standards (FAME Mix C4-C24, Supelco, Bellefonte, PA. USA). Fatty acids were quantified relative to internal standard. All analyses were conduct in duplicate.

\subsection{Total Phenolics Content, DPPH Radical Scavenging Assay, and Determination of Reducing Power}

Layer cakes were sliced into about $1.0 \mathrm{~cm}$ thick and frozen at $-20^{\circ} \mathrm{C}$. Then the slices were lyophilized in a freeze drier (FD4.5 12XL, Kingmech Co. Ltd., New Taipei City, Taiwan). The dried slices were milled and screened through a sieve $(0.5 \mathrm{~mm})$. The ground layer cake samples were stored at $-20^{\circ} \mathrm{C}$. The ground gluten-free layer cake samples $(3 \mathrm{~g})$ were extracted with $22.5 \mathrm{ml}$ of a methanol:acetone:water $(1: 1: 1 ; \mathrm{v} / \mathrm{v} / \mathrm{v})$ using a stirring hot plate (Model PC-420D, Corning, NY, USA) at $1000 \mathrm{rpm}$ for $30 \mathrm{~min}$ according to the method of Seczyk et al. [20] with slight modification. The extracts were centrifuged $(6800 \times g)$ at $4^{\circ} \mathrm{C}$ for $30 \mathrm{~min}$ and extraction procedure was repeated two times. All extracted solutions were combined and stored in darkness at $-20^{\circ} \mathrm{C}$ until analysis.

Total phenolics were evaluated using Folin-Ciocalteau reagent described by Singleton and Rossi [21]. The cake extracted solution $(0.1 \mathrm{ml})$, water $(0.1 \mathrm{ml})$ and FolinCiocalteau reagent $(0.4 \mathrm{ml})$ were mixed, and then $2 \mathrm{ml}$ of sodium carbonate $(100 \mathrm{~g} / 1000 \mathrm{ml})$ was added after $3 \mathrm{~min}$ and mixed thoroughly. It was allowed to stand for $30 \mathrm{~min}$ and measured the absorbance at $700 \mathrm{~nm}$ in a microplate Reader (Model AMR-100, Allsheng Instruments Co., Ltd., Hangzhou City, China). Total phenolics content was calculated as gallic acid equivalents in $\mathrm{mg} / \mathrm{g}$ of dry weight.

The scavenging effects of the layer cake samples for 1,1-diphenyl-2-picrylhydrazyl hydrate (DPPH) were determined spectrophotometrically according to the methods of Shimada et al. [22]. A $1 \mathrm{ml}$ aliquot of layer cake extracted solution was added to $1 \mathrm{ml}$ of $0.1 \mathrm{mM}$ DPPH methanolic solution. The mixture was left to stand at room temperature for $30 \mathrm{~min}$ in the dark. The absorbance was recorded at $517 \mathrm{~nm}$ and the percentage of the radical scavenging effect was calculated using the following equation:

$$
\begin{aligned}
& \text { Scavenging effect }(\%) \\
& =\left(1-\left(\mathrm{A}_{\text {sample }} / \mathrm{A}_{\text {blank }}\right)\right) \times 100 \%
\end{aligned}
$$

where $A_{\text {sample }}$ is the absorbance of the test sample (DPPH plus extracted solutions) and $A_{\text {blank }}$ is the absorbance of water plus methanolic DPPH solution. A reaction mixture containing $30 \mu \mathrm{l}$ of $50 \mu \mathrm{M}$ ascorbic acid and $180 \mu \mathrm{l}$ methanolic DPPH solution $(0.12 \mathrm{mM})$ served as the positive control.

A $1 \mathrm{ml}$ of cake extracted solution was added to $1 \mathrm{ml}$ of sodium phosphate buffer $(0.2 \mathrm{mM}, \mathrm{pH}$ 6.6) followed by 1 $\mathrm{ml}$ of $1 \%$ potassium ferricyanide. The reaction mixture was incubated for $20 \mathrm{~min}$ in a water bath at $50^{\circ} \mathrm{C}$. After incubation, $1 \mathrm{ml}$ of $10 \%$ trichloroacetic acid was added, followed by centrifugation at $1700 \times \mathrm{g}$ for $10 \mathrm{~min}$ at $4{ }^{\circ} \mathrm{C}$. The upper layer $(1 \mathrm{ml})$ was mixed with $1 \mathrm{ml}$ distilled water and $0.2 \mathrm{ml}$ of $0.1 \%$ ferric chloride. Absorbance of the resulting solution was measured at $700 \mathrm{~nm}$. A reaction mixture containing $125 \mu \mathrm{l}$ of DI water served as the blank and $125 \mu \mathrm{l}$ ascorbic acid $(500 \mu \mathrm{M})$ served as the positive control. A high absorbance was indicative of strong reducing power [23].

\subsection{Sensory Evaluation}

Twenty-six male and forty-four female undergraduate and graduate students from the Department of Food Science, between the ages of 18 and 24, were panel participants. Cake samples were coded with three digits and panelists were instructed to evaluate the appearance, 
odor, texture, flavor and overall score using a seven-point hedonic scale ranging from " $1=$ extremely dislike" to "7=extremely like" according to the method of Sudha et al. [24].

\subsection{Statistical Analysis}

Data was examined with an analysis of variance using the SPSS statistic program for Windows Version 12 (SPSS Inc., Chiago, IL, USA). Ducan's multiple range test was used to identify the difference between treatments at a $5 \%$ significance level $(\mathrm{p}<0.05)$. Differences between the means were evaluated using Duncan's Multiple Range Test.

\section{Results and Discussion}

\subsection{Effect of Xanthan Gum and Flaxseed Flour on Batter Properties}

Batter properties of gluten-free layer cakes in the presence of xanthan gum and flaxseed flour added are shown in Table 2. Gluten-free layer cakes containing 60\% flaxseed flour showed highest batter viscosity than the other groups. Regarding the batter density, it showed no differences $(p>0.05)$ compared to those of $0.8 \%$ xanthan gum added and $40 \%$ of flaxseed flour gluten-free cake supplemented (Table 2). Ashwini et al. [25] studied at effect of hydrocolloids like arabic, guar, carrageenan, hydroxypropylcellulose and xanthan in combination with emulsifiers such as glycerol monostearate (GMS) and sodium stearoyl-2-lactylate (SSL) on the rheological, microstructural and quality characteristics of eggless cake. Addition of hydrocolloids to wheat flour as well as in the presence of GMS and SSL increased the eggless cake batter viscosity specific gravity, and xanthan gum showed the highest value. They proposed addition of xanthan gum increased the overall quality of eggless cake with SSL [25].

\subsection{Gluten-Free Layer Cake Volume, Symmetry and Uniformity}

Gluten-free layer cakes made with $0.8 \%$ xanthan gum showed very good quality concerning center height, volume, symmetry and uniformity index (Table 3) and it also showed the lowest hardness and high cohesiveness (Table 4). 1\% Xanthan gum addition decrease the center height, volume $(p<0.05)$ and uniformity index of glutenfree layer cakes. Our results agree with finding of that when adds high levels of soluble gum to gluten-free cake and its volume decrease. It may be due to batter viscosity is over the optimal processing condition. Crumb hardness increases when the batter viscosity is too high which results a lower expansion during baking explains the high crumb hardness and low volume index and center height (Table 3) with $1 \%$ xanthan gum addition. Although cakes containing $0.8 \%$ xanthan gum showed very good quality concerning center height, volume, symmetry and uniformity index (Table 3 ), it showed the lowest crude protein, fat and ash content in proximate composition of gluten-free layer cakes (Table 5).

Table 2. Viscosity and density of gluten-free layer cake batter

\begin{tabular}{ccc}
\hline & Batter density $\left(\mathrm{g} / \mathrm{cm}^{3}\right)$ & Batter viscosity $25^{\circ} \mathrm{C}(\mathrm{cp})$ \\
\hline C & $1.35 \pm 0.03^{\mathrm{a}}$ & $2038.33 \pm 112.26^{\mathrm{d}}$ \\
$\mathrm{F} 20$ & $1.24 \pm 0.04^{\mathrm{b}}$ & $7656.33 \pm 1416.94^{\mathrm{d}}$ \\
$\mathrm{F} 40$ & $1.16 \pm 0.00^{\mathrm{c}}$ & $30412.00 \pm 7390.97^{\mathrm{c}}$ \\
$\mathrm{F} 60$ & $1.14 \pm 0.01^{\mathrm{c}}$ & $97808.11 \pm 27121.28^{\mathrm{a}}$ \\
X & $1.19 \pm 0.05^{\mathrm{bc}}$ & $47596.89 \pm 5002.58^{\mathrm{b}}$ \\
WF & $1.39 \pm 0.01^{\mathrm{a}}$ & $7395.44 \pm 522.57^{\mathrm{d}}$
\end{tabular}

Expressed as mean \pm standard deviation $(n=3)$. Values followed by the different letter within each row are significantly different $(p<0.05)$. C: control gluten-free cake; F20: gluten-free cake supplemented with $20 \%$ of flaxseed flour; F40: gluten-free cake supplemented with $40 \%$ of flaxseed flour; F60: gluten-free cake supplemented with $60 \%$ of flaxseed flour; X: gluten-free cake supplemented with $0.8 \%$ of xanthan gum; WF: cake supplemented with $100 \%$ of wheat flour.

Table 3. Comparison on center height, volume, symmetry and uniformity of gluten-free cake supplemented with xanthan gum.

\begin{tabular}{|c|c|c|c|c|}
\hline & Center height $(\mathrm{cm})$ & volume index* & symmetry index** & uniformity index $* * *$ \\
\hline $\mathrm{X}_{0.2}$ & $8.07 \pm 0.31^{\mathrm{c}}$ & $22.70 \pm 0.44^{\mathrm{d}}$ & $1.50 \pm 0.56^{\mathrm{a}}$ & $0.50 \pm 0.30^{\mathrm{a}}$ \\
\hline $\mathrm{X}_{0.4}$ & $8.80 \pm 0.10^{\mathrm{b}}$ & $24.50 \pm 0.46^{\mathrm{c}}$ & $1.90 \pm 0.69^{\mathrm{a}}$ & $0.23 \pm 0.23^{\mathrm{a}}$ \\
\hline $\mathrm{X}_{0.8}$ & $9.90 \pm 0.10^{\mathrm{a}}$ & $26.93 \pm 0.21^{\mathrm{a}}$ & $2.77 \pm 0.21^{\mathrm{a}}$ & $0.70 \pm 0.44^{\mathrm{a}}$ \\
\hline $\mathrm{X}_{1.0}$ & $9.63 \pm 0.38^{\mathrm{a}}$ & $25.87 \pm 0.35^{\mathrm{b}}$ & $3.03 \pm 1.46^{\mathrm{a}}$ & $0.23 \pm 0.15^{\mathrm{a}}$ \\
\hline $\mathrm{C}$ & $7.83 \pm 0.25^{\mathrm{d}}$ & $23.03 \pm 0.84^{\mathrm{bc}}$ & $0.47 \pm 0.29^{b}$ & $0.20 \pm 0.17^{\mathrm{a}}$ \\
\hline $\mathrm{F} 20$ & $8.43 \pm 0.23^{b}$ & $23.97 \pm 0.31^{\mathrm{b}}$ & $1.33 \pm 0.81^{\mathrm{b}}$ & $0.27 \pm 0.31^{\mathrm{a}}$ \\
\hline F40 & $8.37 \pm 0.06^{\mathrm{bc}}$ & $23.87 \pm 0.31^{\mathrm{b}}$ & $1.23 \pm 0.47^{\mathrm{b}}$ & $0.23 \pm 0.15^{\mathrm{a}}$ \\
\hline F60 & $7.43 \pm 0.32^{\mathrm{d}}$ & $21.33 \pm 0.67^{\mathrm{d}}$ & $0.97 \pm 0.31^{\mathrm{b}}$ & $0.17 \pm 0.12^{\mathrm{a}}$ \\
\hline $\mathrm{X}$ & $9.93 \pm 0.50^{\mathrm{a}}$ & $27.23 \pm 1.00^{\mathrm{a}}$ & $2.57 \pm 0.57^{\mathrm{a}}$ & $0.37 \pm 0.25^{\mathrm{a}}$ \\
\hline
\end{tabular}

Expressed as mean \pm standard deviation $(n=3)$. Values followed by the different letter within each row are significantly different $(p<0.05)$.

* volume index: center height + height of the points halfway from the center to outer edges.

** symmetry index: 2 center height - height of the points halfway from the center to outer edges.

$* * *$ uniformity index: the difference between the points halfway from the center to outer edges.

$\mathrm{X}_{0.2}$ : gluten-free cake supplemented with $0.2 \%$ of xanthan gum; $\mathrm{X}_{0.4}$ : gluten-free cake supplemented with $0.4 \%$ of xanthan gum; $\mathrm{X}_{0.6}$ : gluten-free cake supplemented with $0.6 \%$ of xanthan gum; $\mathrm{X}_{0.8}$ : gluten-free cake supplemented with $0.8 \%$ of xanthan gum; $\mathrm{X}_{1.0}$ : gluten-free cake supplemented with $1.0 \%$ of xanthan gum. C: control gluten-free cake; F20: gluten-free cake supplemented with 20\% of flaxseed flour; F40: gluten-free cake supplemented with $40 \%$ of flaxseed flour; F60: gluten-free cake supplemented with $60 \%$ of flaxseed flour; X: gluten-free cake supplemented with $0.8 \%$ of xanthan gum; WF: cake supplemented with $100 \%$ of wheat flour. 
Table 4. Comparison on texture parameters of gluten-free cake supplemented with xanthan gum.

\begin{tabular}{lllcc}
\hline & Hardness $(\mathrm{N})$ & Cohesiveness & Springiness & Resilience \\
\hline $\mathrm{X}_{0.2}$ & $9.216 \pm 1.813^{\mathrm{a}}$ & $0.577 \pm 0.034^{\mathrm{b}}$ & $0.938 \pm 0.026^{\mathrm{a}}$ & $0.388 \pm 0.042^{\mathrm{a}}$ \\
$\mathrm{X}_{0.4}$ & $7.971 \pm 1.401^{\mathrm{ab}}$ & $0.609 \pm 0.027^{\mathrm{ab}}$ & $0.934 \pm 0.036^{\mathrm{a}}$ & $0.386 \pm 0.050^{\mathrm{a}}$ \\
$\mathrm{X}_{0.6}$ & $5.849 \pm 0.396^{\mathrm{b}}$ & $0.622 \pm 0.008^{\mathrm{a}}$ & $0.934 \pm 0.038^{\mathrm{a}}$ & $0.358 \pm 0.021^{\mathrm{a}}$ \\
$\mathrm{X}_{0.8}$ & $5.788 \pm 0.463^{\mathrm{b}}$ & $0.621 \pm 0.009^{\mathrm{a}}$ & $0.934 \pm 0.036^{\mathrm{a}}$ & $0.372 \pm 0.031^{\mathrm{a}}$ \\
$\mathrm{X}_{1.0}$ & $6.532 \pm 0.956^{\mathrm{b}}$ & $0.610 \pm 0.021^{\mathrm{ab}}$ & $0.935 \pm 0.045^{\mathrm{a}}$ & $0.353 \pm 0.024^{\mathrm{a}}$ \\
\hline
\end{tabular}

Expressed as mean \pm standard deviation $(\mathrm{n}=3)$. Values followed by the different letter within each row are significantly different $(p<0.05)$.

$\mathrm{X}_{0.2}$ : gluten-free cake supplemented with $0.2 \%$ of xanthan gum; $\mathrm{X}_{0.4}$ : gluten-free cake supplemented with $0.4 \%$ of xanthan gum; $\mathrm{X}_{0.6}$ : gluten-free cake supplemented with $0.6 \%$ of xanthan gum; $\mathrm{X}_{0.8}$ : gluten-free cake supplemented with $0.8 \%$ of xanthan gum; $\mathrm{X}_{1.0}$ : gluten-free cake supplemented with $1.0 \%$ of xanthan gum.

Table 5. Proximate composition of gluten-free cake.

\begin{tabular}{cccccc}
\hline & Moisture (\%) & Crude protein (\%) & Crude fat (\%) & Ash (\%) & Carbohydrate* (\%) \\
\hline C & $29.94 \pm 1.57^{\mathrm{ab}}$ & $2.09 \pm 0.09^{\mathrm{e}}$ & $7.45 \pm 0.27^{\mathrm{e}}$ & $1.22 \pm 0.04^{\mathrm{e}}$ & $59.30 \pm 1.54^{\mathrm{a}}$ \\
F20 & $30.27 \pm 0.84^{\mathrm{a}}$ & $2.42 \pm 0.12^{\mathrm{c}}$ & $9.03 \pm 0.24^{\mathrm{c}}$ & $1.45 \pm 0.07^{\mathrm{c}}$ & $56.83 \pm 0.76^{\mathrm{b}}$ \\
F40 & $29.01 \pm 1.51^{\mathrm{ab}}$ & $2.78 \pm 0.20^{\mathrm{b}}$ & $10.34 \pm 0.90^{\mathrm{b}}$ & $1.65 \pm 0.07^{\mathrm{b}}$ & $56.22 \pm 2.10^{\mathrm{b}}$ \\
F60 & $28.34 \pm 1.35^{\mathrm{c}}$ & $3.34 \pm 0.19^{\mathrm{a}}$ & $12.48 \pm 0.88^{\mathrm{a}}$ & $1.83 \pm 0.06^{\mathrm{a}}$ & $54.01 \pm 1.42^{\mathrm{a}}$ \\
X & $30.21 \pm 1.07^{\mathrm{a}}$ & $2.01 \pm 0.13^{\mathrm{e}}$ & $7.25 \pm 1.23^{\mathrm{e}}$ & $1.21 \pm 0.05^{\mathrm{e}}$ & $59.31 \pm 0.72^{\mathrm{a}}$ \\
WF & $28.65 \pm 2.78^{\mathrm{ab}}$ & $2.26 \pm 0.15^{\mathrm{d}}$ & $8.82 \pm 1.31^{\mathrm{d}}$ & $1.30 \pm 0.04^{\mathrm{d}}$ & $58.96 \pm 1.68^{\mathrm{a}}$ \\
\hline
\end{tabular}

Expressed as mean \pm standard deviation $(\mathrm{n}=3)$. Values followed by the different letter within each row are significantly different $(p<0.05)$.

*Carbohydrate: $100 \%$ - Moisture - Ash - Crude fat - Crude protein.

C: control gluten-free cake; F20: gluten-free cake supplemented with $20 \%$ of flaxseed flour; F40: gluten-free cake supplemented with $40 \%$ of flaxseed flour; F60: gluten-free cake supplemented with $60 \%$ of flaxseed flour; X: gluten-free cake supplemented with $0.8 \%$ of xanthan gum; WF: cake supplemented with $100 \%$ of wheat flour.

The volume, symmetry, and uniformity indices for gluten-free layer cakes supplemented with flaxseed flour are listed in Table 3. Significantly higher center height $(\mathrm{p}<0.05)$ of $20 \%$ and $40 \%$ flaxseed flour replaced rice flour gluten-free layer cakes were found. The gluten-free layer cake volume not only depends on the air incorporated into the batter, but also on the air retained on the air produced by the baking powder during processing and on the formation of a stable structure during baking [26]. The center height, volume index, symmetry index and uniformity index decreased as the replaced amount reach $60 \%$. Studies on xanthan gum addition (0.2-1.0\%) have shown that xanthan gum addition can increase batter viscosity (data not shown) and improve the center height, volume, symmetry and uniformity of gluten-free cake to the highest index values of $0.8 \%$ xanthan gum addition (Table 3 ).

Soluble fiber increases the batter viscosity and may allow for the formation of starch-protein or starch-lipid complexes which stabilize the cake batter during baking. The rice flour forms a weaker gel system than xanthan gum added or flaxseed flour replacement due to the less extensive swelling of the starch granule. These positive effects of xanthan gum added or flaxseed flour replacement seem to resonate in experiment. Batter viscosity increased with specific gravity decreased meaning more air bubbles were trapped in the batter system [7].

\subsection{Color and Texture of Gluten-Free Layer Cakes}

The color of the gluten-free layer cakes plays an important role in consumers' acceptability and perception of the cake. The crust and crumb color parameters L, a, b, white index (WI) and $\Delta \mathrm{E}$ are represented in Table 6. Increase in flaxseed flour supplement from 0 to $60 \%$ led to a significant decrease $(\mathrm{p}<0.05)$ in the darkness ( $\mathrm{L}$ value) and $\Delta \mathrm{E}$ of the crust and crumb of the gluten-free layer cakes (Table 6). WI and $\Delta \mathrm{E}$ of flaxseed flour reduced bread crumb and crust color values was observed by Garden [27] and it was proposed due to the Maillard reactions related to flaxseed phenolic compounds and protein. No significant difference ( $p>0.05)$ was found in crust WI and $\Delta \mathrm{E}$ of the gluten-free layer cakes with $0.8 \%$ xanthan gum addition comparing to those of $40 \%$ flaxseed flour replacement (Table 6). However, the higher L values and WI in the crumb of $0.8 \%$ xanthan gum addition observed for glutenfree layer cakes are possibly related to less Maillard reaction were occurred in the crumb section of cakes.

The gluten-free layer cakes with $60 \%$ flaxseed flour replacement were significantly darker than the control as indicated by lower L, a, b values and WI on the crust and crumb (Table 6). Marpalle et al. [28] reported that the crumb and crust $L$ and $b$ values decreased and a value increased with increasing flaxseed flour levels from 0 to $15 \%$ in bread formulations. The effect of flaxseed flour on the hardness and springiness is presented in Table 7. The hardness and springiness of gluten-free layer cake decrease significantly $(p<0.05)$ with flaxseed flour supplement in cakes. In general, cake hardness is related to the development of gluten and the interaction with other wheat flour ingredients such as milk, eggs, sugar and baking powder in the formula [29].

The decrease in the hardness of cakes as the flaxseed flour replaced rice flour level increased in gluten-free layer cakes may be attributed to the increase in oil and flaxseed gum content from flaxseed flour. The increase in the hardness of cakes as the flaxseed flour replaced rice flour level at $60 \%$ in gluten-free layer cakes may cause the batter viscosity too high to expand the cake structure which forms a compact structure and may be also attributed the increase in protein content from flaxseed flour. The higher protein content and lower starch content of flaxseed flour may also influence the development of the gluten-free layer cake, since starch is responsible for achieving the final structure, gelatinizing and increasing the consistency of the batter during baking [6]. 
Table 6. Colour of gluten-free cake crust and crumb

\begin{tabular}{|c|c|c|c|c|c|}
\hline Crust & $\mathrm{L}$ & $\mathrm{a}$ & b & W.I.* & $\Delta \mathrm{E}^{* *}$ \\
\hline $\mathrm{C}$ & $32.42 \pm 1.57^{\mathrm{a}}$ & $12.87 \pm 0.83^{\mathrm{a}}$ & $16.78 \pm 0.65^{\mathrm{ab}}$ & $29.18 \pm 1.46^{\mathrm{a}}$ & - \\
\hline $\mathrm{F} 20$ & $30.12 \pm 1.98^{b}$ & $12.83 \pm 0.97^{\mathrm{a}}$ & $15.78 \pm 0.91^{\mathrm{c}}$ & $27.20 \pm 1.72^{\mathrm{ab}}$ & $3.03 \pm 1.93^{\mathrm{d}}$ \\
\hline F60 & $25.28 \pm 2.14^{\mathrm{c}}$ & $9.61 \pm 047^{\mathrm{c}}$ & $12.35 \pm 0.81^{\mathrm{e}}$ & $23.65 \pm 1.99^{c}$ & $9.25 \pm 2.90^{\mathrm{a}}$ \\
\hline $\mathrm{X}$ & $30.33 \pm 6.16^{\mathrm{b}}$ & $11.62 \pm 1.11^{\mathrm{b}}$ & $17.34 \pm 0.88^{\mathrm{a}}$ & $27.25 \pm 5.94^{\mathrm{ab}}$ & $6.86 \pm 3.26^{\mathrm{ab}}$ \\
\hline WF & $32.78 \pm 2.68^{\mathrm{a}}$ & $11.33 \pm 0.97^{\mathrm{b}}$ & $16.07 \pm 1.15^{\mathrm{bc}}$ & $29.94 \pm 2.39^{\mathrm{a}}$ & $4.09 \pm 2.22^{\mathrm{cd}}$ \\
\hline \multicolumn{6}{|l|}{ Crumb } \\
\hline $\mathrm{C}$ & $76.51 \pm 2.60^{\mathrm{b}}$ & $-2.00 \pm 0.60^{\mathrm{d}}$ & $26.08 \pm 0.52^{\mathrm{a}}$ & $64.79 \pm 1.76^{\mathrm{b}}$ & - \\
\hline F20 & $69.37 \pm 0.85^{\mathrm{c}}$ & $-0.03 \pm 0.48^{\mathrm{c}}$ & $23.51 \pm 0.48^{\mathrm{c}}$ & $61.38 \pm 0.57^{\mathrm{c}}$ & $7.94 \pm 2.51^{\mathrm{c}}$ \\
\hline F40 & $59.33 \pm 1.58^{d}$ & $-1.55 \pm 0.32^{b}$ & $21.17 \pm 0.49^{\mathrm{d}}$ & $54.11 \pm 1.23^{\mathrm{d}}$ & $18.26 \pm 3.92^{b}$ \\
\hline F60 & $49.29 \pm 2.34^{\mathrm{e}}$ & $-3.28 \pm 0.35^{\mathrm{a}}$ & $19.68 \pm 0.42^{\mathrm{e}}$ & $45.49 \pm 2.06^{\mathrm{e}}$ & $28.48 \pm 2.68^{\mathrm{a}}$ \\
\hline $\mathrm{X}$ & $80.97 \pm 3.30^{\mathrm{a}}$ & $-2.99 \pm 0.27^{\mathrm{e}}$ & $24.92 \pm 1.01^{\mathrm{b}}$ & $68.36 \pm 1.35^{\mathrm{a}}$ & $5.26 \pm 1.35^{\mathrm{d}}$ \\
\hline
\end{tabular}

Expressed as mean \pm standard deviation $(\mathrm{n}=3)$. Values followed by the different letter within each row are significantly different $(p<0.05)$.

* W.I.: $100-\left[(100-\mathrm{L})^{2}+\mathrm{a}^{2}+\mathrm{b}^{2}\right]^{1 / 2}$

$* * \Delta \mathrm{E}:\left[\left(\mathrm{L}_{\text {sample }}-\mathrm{L}_{\text {control }}\right)^{2}+\left(\mathrm{a}_{\text {sample }}-\mathrm{a}_{\text {control }}\right)^{2}+\left(\mathrm{b}_{\text {sample }}-\mathrm{b}_{\text {control }}\right)^{2}\right]^{1 / 2}$

C: control gluten-free cake; F20: gluten-free cake supplemented with $20 \%$ of flaxseed flour; F40: gluten-free cake supplemented with $40 \%$ of flaxseed flour; F60: gluten-free cake supplemented with $60 \%$ of flaxseed flour; X: gluten-free cake supplemented with $0.8 \%$ of xanthan gum; WF: cake supplemented with $100 \%$ of wheat flour.

Table 7. Hardness and springiness changes of gluten-free cake during 6 days storage at room temperature.

\begin{tabular}{|c|c|c|c|c|}
\hline Hardness (N) & Day0 & Day2 & Day4 & Day6 \\
\hline $\mathrm{C}$ & $11.170 \pm 1.720^{\mathrm{aD}}$ & $17.387 \pm 1.663^{\mathrm{aC}}$ & $22.696 \pm 2.603^{\mathrm{aB}}$ & $34.064 \pm 5.232^{\mathrm{aA}}$ \\
\hline $\mathrm{F} 20$ & $7.392 \pm 0.745^{\mathrm{bD}}$ & $10.338 \pm 0.443^{\mathrm{bC}}$ & $14.043 \pm 1.115^{\mathrm{cB}}$ & $16.306 \pm 1.660^{\mathrm{cA}}$ \\
\hline F60 & $6.081 \pm 0.714^{\mathrm{cD}}$ & $7.777 \pm 0.390^{\mathrm{cC}}$ & $10.302 \pm 1.098^{\mathrm{dB}}$ & $12.739 \pm 1.501^{\mathrm{dA}}$ \\
\hline$X$ & $5.432 \pm 0.588^{\mathrm{cD}}$ & $10.636 \pm 0.318^{\mathrm{bC}}$ & $14.722 \pm 0.809^{\mathrm{cB}}$ & $17.562 \pm 2.689^{\mathrm{cA}}$ \\
\hline WF & $11.376 \pm 0.785^{\mathrm{aD}}$ & $17.657 \pm 2.554^{\mathrm{aC}}$ & $21.082 \pm 1.760^{\mathrm{bB}}$ & $26.332 \pm 5.429^{\mathrm{bA}}$ \\
\hline \multicolumn{5}{|l|}{ Springiness } \\
\hline $\mathrm{C}$ & $0.916 \pm 0.024^{\mathrm{bA}}$ & $0.893 \pm 0.015^{\mathrm{bAB}}$ & $0.863 \pm 0.031^{\mathrm{bcBC}}$ & $0.834 \pm 0.094^{\mathrm{cC}}$ \\
\hline $\mathrm{F} 20$ & $0.905 \pm 0.024^{\mathrm{bA}}$ & $0.892 \pm 0.028^{\mathrm{bAB}}$ & $0.875 \pm 0.032^{\mathrm{bBC}}$ & $0.857 \pm 0.019^{\mathrm{abC}}$ \\
\hline F40 & $0.871 \pm 0.026^{\mathrm{cA}}$ & $0.863 \pm 0.011^{\mathrm{cAB}}$ & $0.858 \pm 0.017^{\mathrm{bcAB}}$ & $0.842 \pm 0.026^{\mathrm{abB}}$ \\
\hline F60 & $0.839 \pm 0.030^{\mathrm{dA}}$ & $0.865 \pm 0.040^{\mathrm{cA}}$ & $0.842 \pm 0.029^{\mathrm{cA}}$ & $0.833 \pm 0.028^{\mathrm{cA}}$ \\
\hline$X$ & $0.942 \pm 0.023^{\mathrm{aA}}$ & $0.939 \pm 0.025^{\mathrm{aA}}$ & $0.925 \pm 0.028^{\mathrm{aA}}$ & $0.888 \pm 0.015^{\mathrm{aB}}$ \\
\hline WF & $0.902 \pm 0.016^{\mathrm{bA}}$ & $0.885 \pm 0.027^{\mathrm{bcAB}}$ & $0.877 \pm 0.011^{\mathrm{bBC}}$ & $0.861 \pm 0.028^{\mathrm{abC}}$ \\
\hline
\end{tabular}

Expressed as mean \pm standard deviation $(n=3)$. ${ }^{\text {a-d }}$ Indicate significant difference between different samples $(p<0.05)$. ${ }^{\text {A-D }}$ Indicate significant difference between different days $(p<0.05)$.

C: control gluten-free cake; F20: gluten-free cake supplemented with 20\% of flaxseed flour; F40: gluten-free cake supplemented with 40\% of flaxseed flour; F60: gluten-free cake supplemented with $60 \%$ of flaxseed flour; X: gluten-free cake supplemented with $0.8 \%$ of xanthan gum; WF: cake supplemented with $100 \%$ of wheat flour.

The hardness of gluten-free layer cakes increased as the time of storage increased (Figure 1A). The control rice flour group had the highest hardness $(11.17 \mathrm{~N})$, while the gluten-free layer cake with $0.8 \%$ xanthan gum addition had the lowest $(5.43 \mathrm{~N})$ followed by that of $40 \%$ and $60 \%$ flaxseed flour replaced rice flour (Figure 1A). The decrease in hardness may be related the amount of air, oil and gum incorporated into the gluten-free batter during mixing.

Incorporation of flaxseed flour reduced the batter density of gluten-free layer cake batter. This increase in amount of oil, flaxseed gum and air bubbles in the cake batter seems to translate into a softer gluten-free layer cake. Xanthan gum addition $(0.2-0.8 \%)$ has been shown to improve center height, volume index, symmetry index, texture and cohesiveness of gluten-free layer cakes (Table 3 $\&$ Table 4). Hardness increased during 6 days storage at $25^{\circ} \mathrm{C}$, and this indicates the gluten-free layer cakes had become stale. However, replacement of rice flour with flaxseed flour can mitigate the rate of hardness increase in gluten-free layer cakes (Figure 1A and Table 7).

Correlation was tested using different amounts of flaxseed flour replacement during 6 days storage at hardness increase (Figure 1A). The predicted equation was used to make predictions of the hardness increase of gluten-free layer cake, as the storage time was observed. The hardness increase showed a negative relationship with the flaxseed flour replacement increase. As Figure 1A shows, the slope of predicted equation decreased based on hardness change of flaxseed flour supplement during 6 days storage. The regression equation for the correlation $\left(\mathrm{R}^{2}\right)$ is all above 0.95 . The regression equation established for the gluten-free layer cake baking could possibly serve as a simple predictive method to determine the mitigation of hardness increase within the amount of flaxseed flour 
replacement and storage time. Springiness of gluten-free layer cake could also be predicted as the predicted method as Table $7 \&$ Figure 1B demonstrated except $60 \%$ flaxseed flour replaced group. This may be due to high batter viscosity in the $60 \%$ flaxseed flour replaced gluten-free layer cake decreased the expansion of cake during baking.

In this study, moisture contents of gluten-free layer cake crust were in the ranges of 10.97 to $14.41 \%$ after baking. It increased dramatically to the ranges of 18.33 after 2 days of storage at $25^{\circ} \mathrm{C}$ to $21.62 \%$. Moisture contents of cake crumb were in the ranges of 25.98 to $28.37 \%$ after baking. It decreased slightly to the ranges of 24.27 to $27.76 \%$ after 6 days of storage at $25^{\circ} \mathrm{C}$. It is due to the moisture migrating from crumb to the crust during storage. Although xanthan gum and flaxseed flour containing water binding polysaccharide, it does not mitigate the migration of moisture. Similar phenomenon was also observed at water activity of the crust and crumb of gluten-free layer cake storage at $25^{\circ} \mathrm{C}$ for 6 days.

\section{(A)}

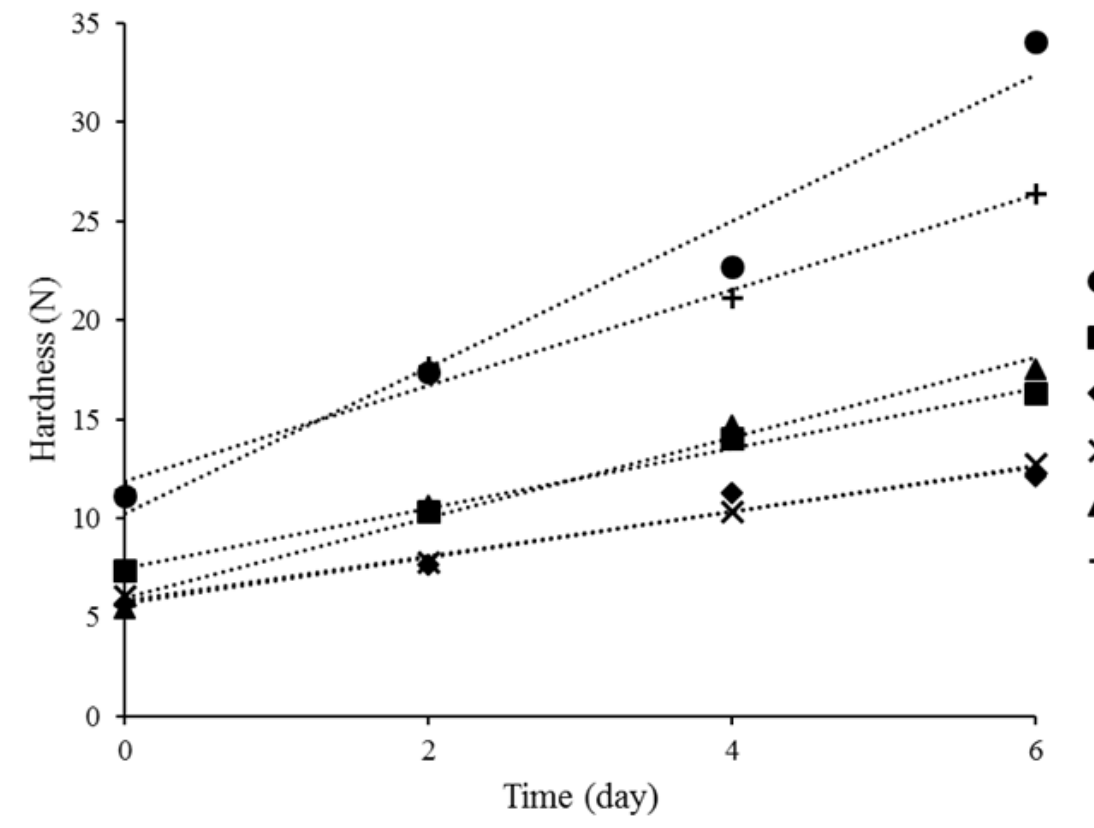

(B)

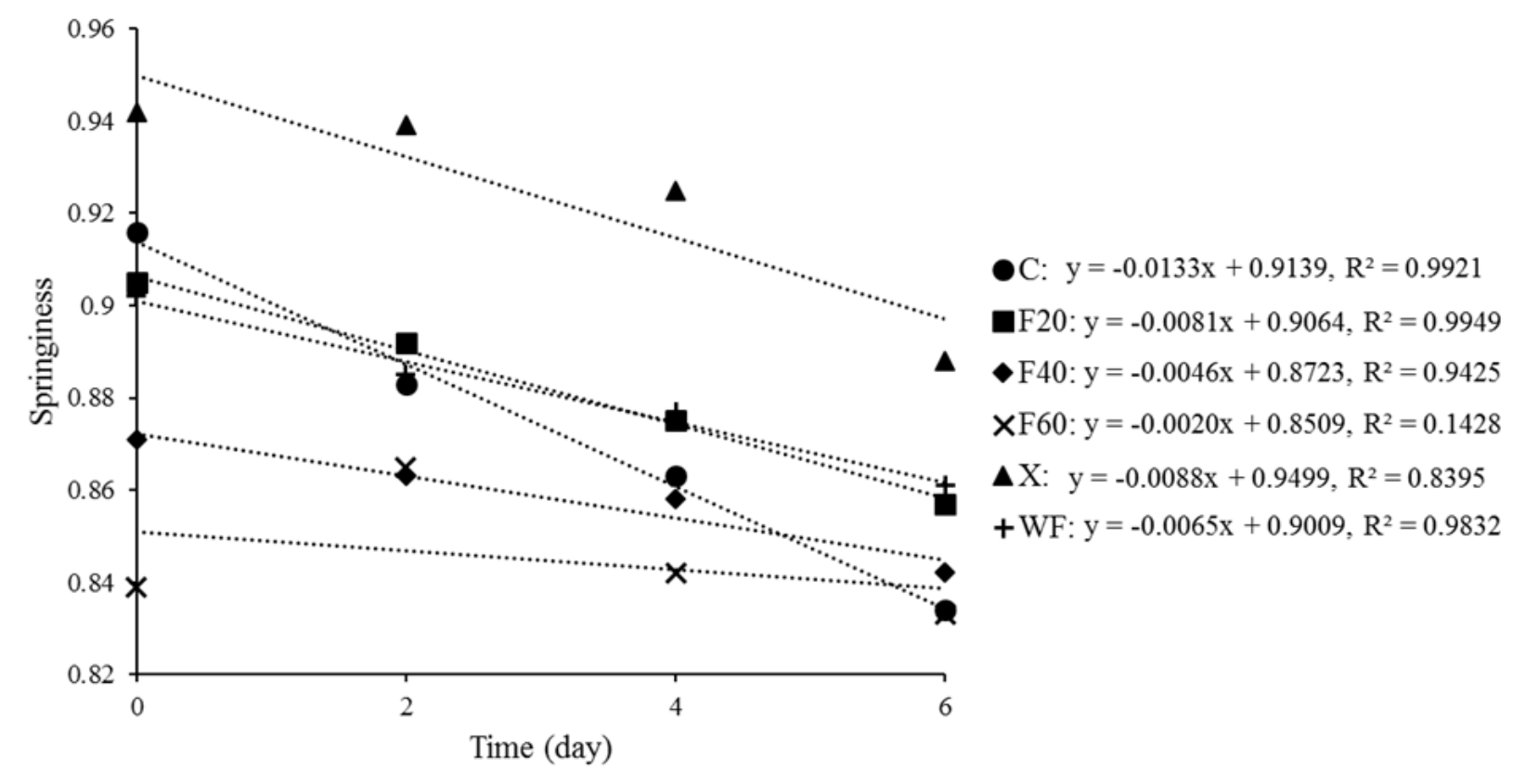

C: control gluten-free cake; F20: gluten-free cake supplemented with 20\% of flaxseed flour; F40: gluten-free cake supplemented with 40\% of flaxseed flour; F60: gluten-free cake supplemented with $60 \%$ of flaxseed flour; X: gluten-free cake supplemented with $0.8 \%$ of xanthan gum; WF: cake supplemented with $100 \%$ of wheat flour.

Figure 1. Hardness (A) and Springiness (B) change of gluten-free layer cake storage at room temperature for 6 days and its predicted linear regression equation. 
(A)

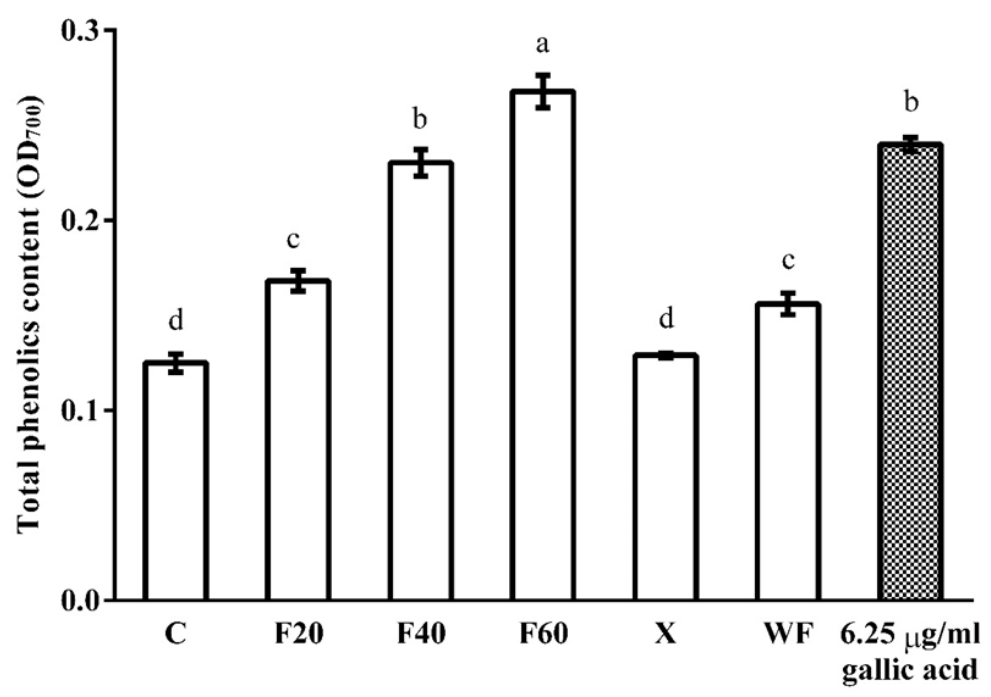

(B)

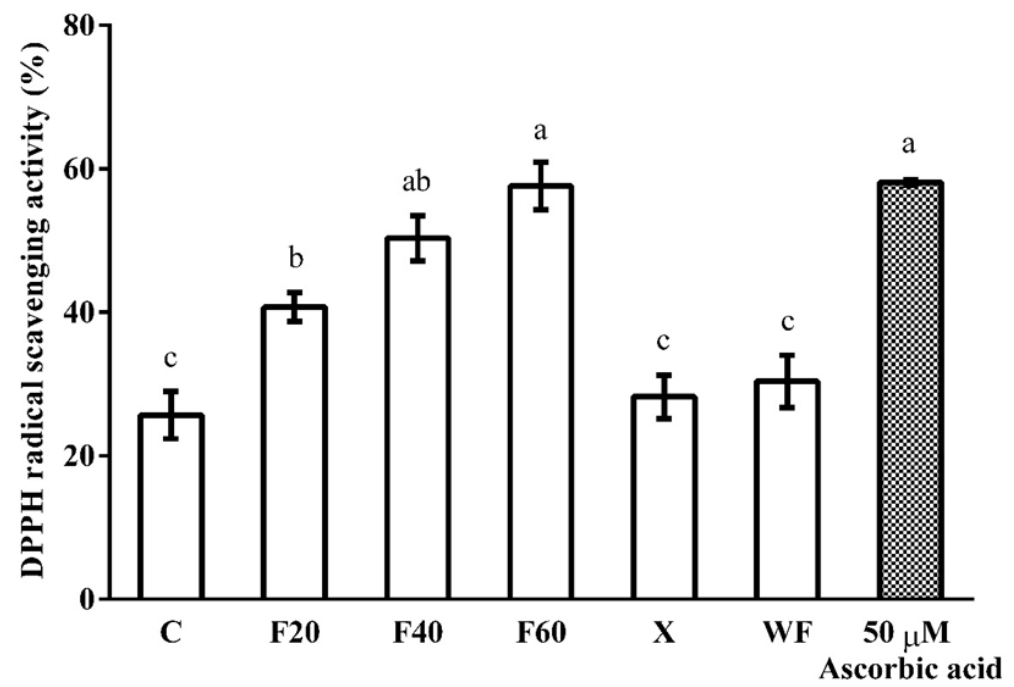

(C)

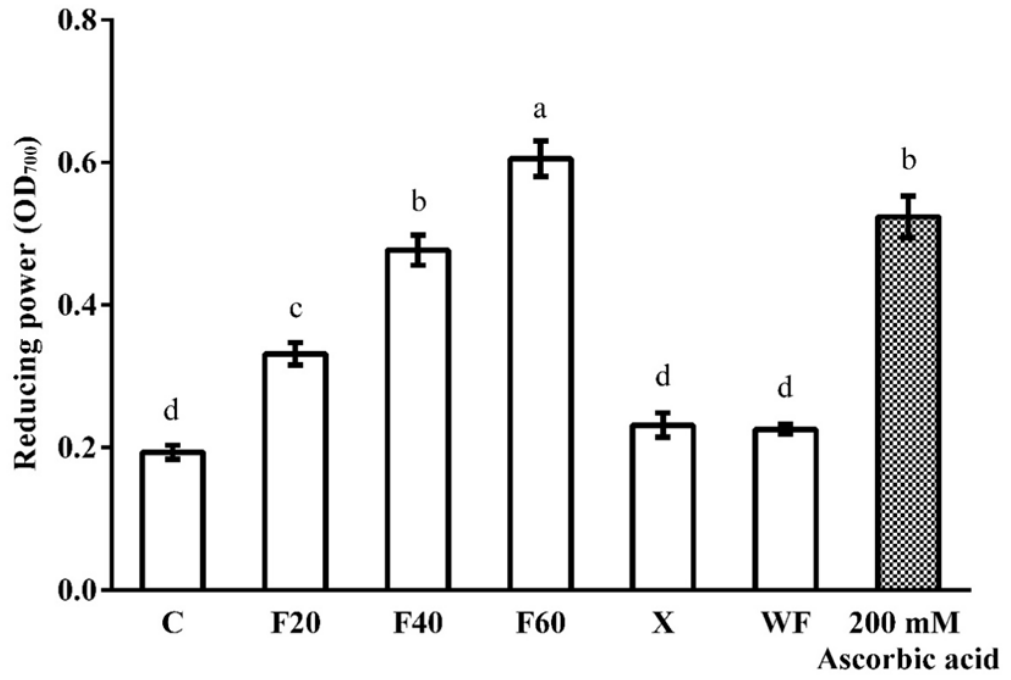

a-d Indicate significant difference between different samples $(n=3 ; p<0.05)$.

C: control gluten-free cake; F20: gluten-free cake supplemented with $20 \%$ of flaxseed flour; F40: gluten-free cake supplemented with $40 \%$ of flaxseed flour; F60: gluten-free cake supplemented with $60 \%$ of flaxseed flour; X: gluten-free cake supplemented with $0.8 \%$ of xanthan gum; WF: cake supplemented with $100 \%$ of wheat flour.

Figure 2. Total phenolics content (A), DPPH radical scavenging activity (B), and Reducing power (C) of gluten-free layer cake 


\section{Crumb structure}

C

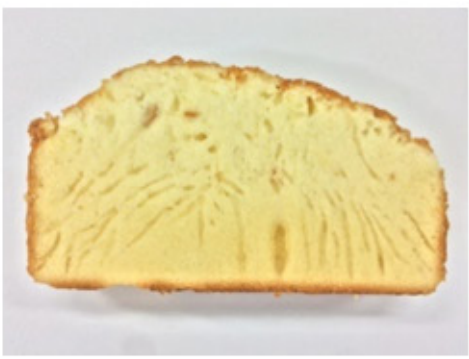

F20

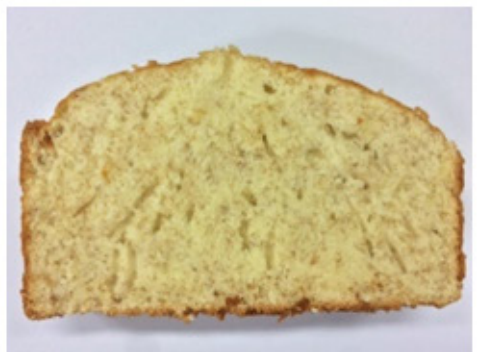

F40

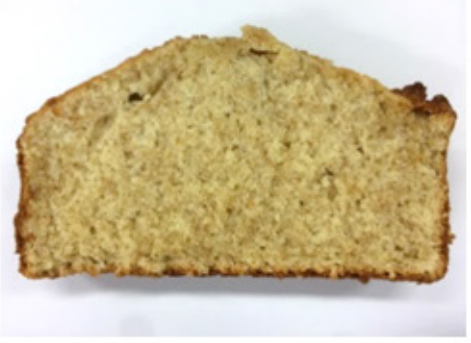

F60

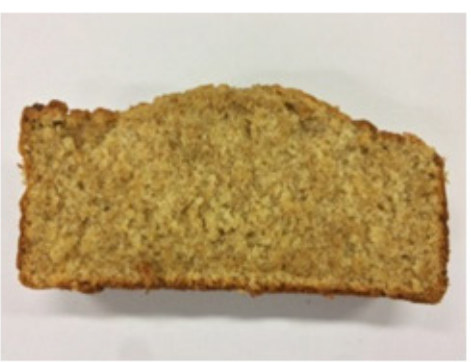

X

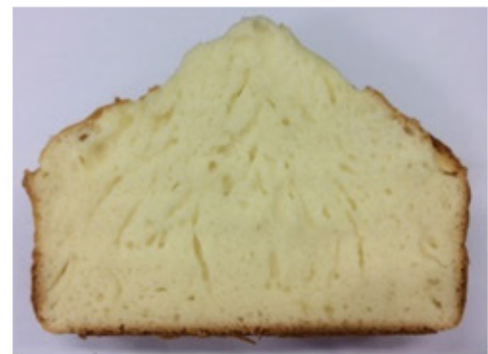

WF

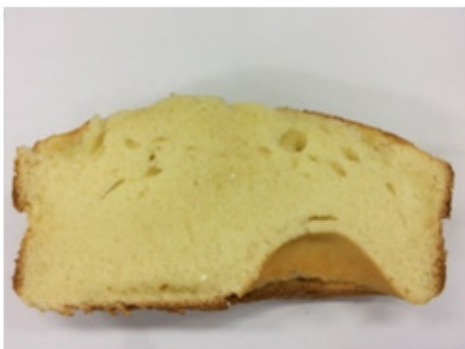

Appearance
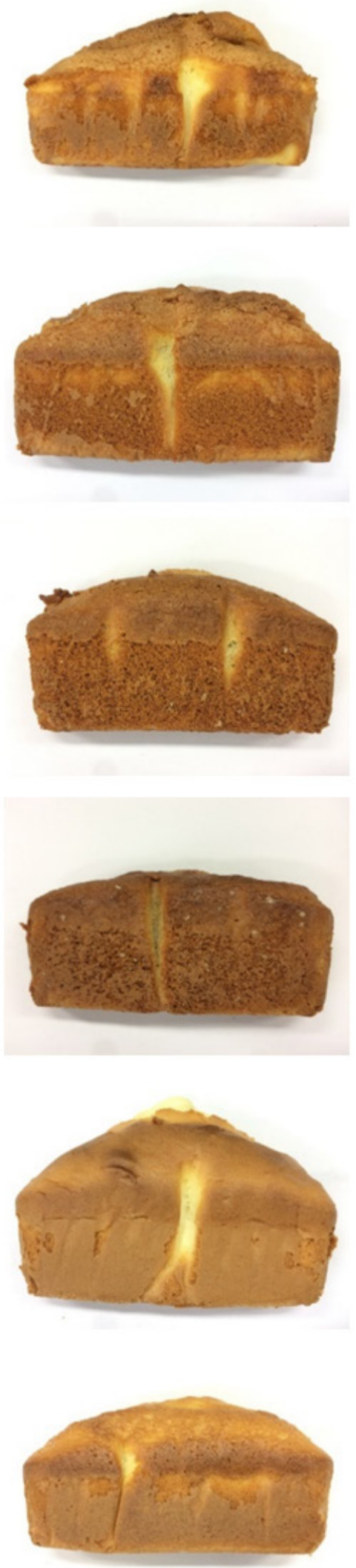

C: control gluten-free cake; F20: gluten-free cake supplemented with 20\% of flaxseed flour; F40: gluten-free cake supplemented with $40 \%$ of flaxseed flour; F60: gluten-free cake supplemented with $60 \%$ of flaxseed flour; X: gluten-free cake supplemented with $0.8 \%$ of xanthan gum; WF: cake supplemented with $100 \%$ of wheat flour. 


\subsection{Fatty Acid Composition of Gluten-Free Layer Cake}

The fatty acids profile of gluten-free layer cake is shown in Table 4. $\alpha$-Linolenic acid was the most prevalent fatty acid of flaxseed flour (>50\%) [30]. $\alpha$-Linolenic acid is found in flaxseed and many vegetable oils and nut [31]. The changes in fatty acids profile associated to flaxseed flour replacement. $\alpha$-Linolenic acid increased from $0.29 \%$ of control group to $14.67 \%$ with $60 \%$ flaxseed flour replaced rice flour (data not shown) in the cake. Chetana et al. [32] observed muffin made of wheat flour substituted with $0-40 \%$ flaxseed and its $\alpha$-linolenic acid level increased from $1 \%$ to $15 \%$. Consumption of a diet rich in n-3 fatty acid was shown to decrease blood pressure and blood lipids, and the risk of blood clotting [33].

\subsection{Phenolics Content and Antioxidant Potential of Gluten-Free Layer Cakes}

The effect of flaxseed flour supplement of gluten-free layer cake on the phenolics content and antioxidant activity is present in Figure 2. Addition of flaxseed flour increased the phenolics content and antioxidant activity of gluten-free layer cakes. In comparison to the control, the content of phenolics in cake extracts was significantly higher by about $34.69 \%, 84.2 \%$ and $114.3 \%$ in the gluten-free layer cake replaced with $20 \%, 40 \%$ and $60 \%$ of flaxseed flour, respectively (Figure 2A).

The scavenging activity of gluten-free layer cakes on the DPPH radical is shown in Figure $2 \mathrm{~B}$. The DPPH radical scavenging activity of $60 \%$ flaxseed flour replaced group is similar to that of $50 \mu \mathrm{M}$ ascorbic acid. The DPPH radical scavenging activities of ascorbic acid, control, $20 \%, 40 \%$ and $60 \%$ flaxseed flour replaced groups were $58.12 \%, 25.67 \%, 40.73 \%, 50.32 \%$ and $57.61 \%$, respectively (Figure 2B). This indicates that flaxseed flour addition could increase the DPPH radical scavenging activity of gluten-free layer cake (Table $9, \mathrm{R}^{2}=0.807 ; \mathrm{p}<0.01$ ). DPPH radical scavenging activity increased $96 \%$ with $40 \%$ flaxseed flour supplement. The reducing powers of glutenfree layer cakes are shown in Figure 2C. Cake supplemented with $40 \%$ flaxseed flour showed a reducing power as high as $200 \mathrm{mM}$ ascorbic acid. The reducing power of glutenfree layer cake, $0.8 \%$ xanthan gum addition and layer cake made from wheat flour exhibited lower values than those of flaxseed flour supplemented groups (Figure 2C). The reducing power of $60 \%$ flaxseed flour replaced group was higher when compared with the groups above (Figure 2C). The addition of flaxseed and its by-product to the cereal-based products was showed improving their antioxidant potential and phenolics content $[13,20,34,35]$.

\subsection{Appearance and Sensory Evaluation of Gluten-Free Layer Cake}

The crust and crumb of gluten-free layer cake supplemented with flaxseed flour was darker than that of the control (Figure 3). The cake volume of $20 \%, 40 \%$ flaxseed flour and $0.8 \%$ xanthan gum added groups were higher than that of control group (Figure 3). Therefore, optimizing the gluten-free layer cake formulation with 20$40 \%$ flaxseed flour and less than $0.8 \%$ xanthan gum could improve the physicochemical qualities and sensory acceptability of cake (Figure $3 \&$ Table 8 ).

The results of hedonic tests on gluten-free layer cake supplemented with flaxseed are summarized in Table 8. The appearance, aroma, texture, flavor and overall acceptability of gluten-free layer cake slightly decreased with flaxseed flour addition. 60\% Flaxseed flour supplement caused a less acceptable in appearance. The gluten-free layer cake of $60 \%$ flaxseed flour supplement received lower scores on all sensory attributes may correspond to the cake is darker in color, greasy and sticky on the crumb. Nevertheless, all sensory characteristics of $0.8 \%$ xanthan gum added gluten-free layer cake were higher than all the other tested groups and control followed by $40 \%$ flaxseed flour supplemented group in aroma, texture, flavor and overall acceptability (Table 8 ). Sensory characteristics of all tested groups were all acceptable except the appearance score of $60 \%$ flaxseed flour supplemented cake less than 4 (Table 8). The data are in agreement with the results of cookies and muffins [36,37] prepared with flaxseed. They reported that majority of panelists rated the control cookies and muffins higher than the highest amount of flaxseed addition for all sensory attributes.

A correlation analysis was evaluated between the physicochemical properties in order to better understand the relationships among different quality attributes (Table 9). Crust color parameters L (-0.83), a (-0.81), b (-0.89), hardness $(-0.79)$ and springiness $(-0.76)$ of gluten-free layer cakes were negative correlated with the amount of flaxseed flour supplement $(\mathrm{p}<0.01)$. However, batter viscosity (0.86), phenolics content (0.94), DPPH (0.81) and reducing power $(0.94)$ were strongly correlated with the amount of flaxseed flour addition $(\mathrm{p}<0.01)$ (Table 9). These results suggest that the phenolics content attribute best predicted antioxidant for gluten-free layer cakes and it's mainly due to the amount of flaxseed flour supplemented.

Table 8. Sensory evaluation of gluten-free layer cake.

\begin{tabular}{|c|c|c|c|c|c|}
\hline & Appearance & Aroma & Texture & Flavor & Overall Acceptability \\
\hline $\mathrm{C}$ & $5.23 \pm 1.16^{\mathrm{a}}$ & $4.29 \pm 1.08^{\mathrm{b}}$ & $4.24 \pm 1.32^{\mathrm{b}}$ & $4.16 \pm 1.22^{\mathrm{b}}$ & $4.46 \pm 1.19^{\mathrm{abc}}$ \\
\hline F20 & $4.31 \pm 1.11^{\mathrm{b}}$ & $4.34 \pm 1.15^{\mathrm{ab}}$ & $4.51 \pm 1.30^{\mathrm{ab}}$ & $4.40 \pm 1.32^{\mathrm{ab}}$ & $4.41 \pm 1.31^{\mathrm{bc}}$ \\
\hline F40 & $4.09 \pm 1.25^{\mathrm{bc}}$ & $4.43 \pm 1.12^{\mathrm{ab}}$ & $4.59 \pm 1.25^{\mathrm{ab}}$ & $4.47 \pm 1.33^{\mathrm{ab}}$ & $4.57 \pm 1.17^{\mathrm{ab}}$ \\
\hline F60 & $3.77 \pm 1.25^{\mathrm{c}}$ & $4.27 \pm 1.21^{b}$ & $4.20 \pm 1.28^{\mathrm{b}}$ & $4.00 \pm 1.47^{b}$ & $4.06 \pm 1.37^{\mathrm{c}}$ \\
\hline $\mathrm{X}$ & $5.46 \pm 1.00^{\mathrm{a}}$ & $4.73 \pm 1.14^{\mathrm{a}}$ & $4.81 \pm 1.27^{\mathrm{a}}$ & $4.67 \pm 1.07^{\mathrm{a}}$ & $4.90 \pm 1.13^{\mathrm{a}}$ \\
\hline WF & $5.27 \pm 1.08^{\mathrm{a}}$ & $4.51 \pm 1.25^{\mathrm{ab}}$ & $4.29 \pm 1.50^{\mathrm{b}}$ & $4.39 \pm 1.40^{\mathrm{ab}}$ & $4.51 \pm 1.34^{\mathrm{ab}}$ \\
\hline
\end{tabular}

Expressed as mean \pm standard deviation $(\mathrm{n}=70)$. Values followed by the different letter within each row are significantly different $(p<0.05)$.

1-7 scale: $1=$ dislike very much, $7=$ like very much.

C: control gluten-free cake; F20: gluten-free cake supplemented with $20 \%$ of flaxseed flour; F40: gluten-free cake supplemented with $40 \%$ of flaxseed flour; F60: gluten-free cake supplemented with $60 \%$ of flaxseed flour; X: gluten-free cake supplemented with $0.8 \%$ of xanthan gum; WF: cake supplemented with $100 \%$ of wheat flour. 
Table 9. The correlation coefficient between the amount of flaxseed flour and the test results.

\begin{tabular}{|c|c|c|c|c|c|c|c|c|c|c|}
\hline & $\begin{array}{c}\text { Amount of } \\
\text { flaxseed flour }\end{array}$ & $\begin{array}{c}\text { Phenolics } \\
\text { content }\end{array}$ & DPPH & $\begin{array}{l}\text { Reducing } \\
\text { power }\end{array}$ & $\begin{array}{c}\mathrm{L} \\
\text { (crust) }\end{array}$ & $\begin{array}{c}\mathrm{a} \\
\text { (crust) }\end{array}$ & $\begin{array}{c}\mathrm{b} \\
\text { (crust) }\end{array}$ & $\begin{array}{c}\text { Batter } \\
\text { viscosity }\end{array}$ & Hardness & Springiness \\
\hline $\begin{array}{l}\text { Amount of flaxseed } \\
\text { flour }\end{array}$ & 1 & & & & & & & & & \\
\hline Phenolics content & $0.944^{* *}$ & 1 & & & & & & & & \\
\hline DPPH & $0.807^{* *}$ & $0.822^{* *}$ & 1 & & & & & & & \\
\hline Reducing power & $0.945^{* *}$ & $0.931^{* *}$ & $0.808^{* *}$ & 1 & & & & & & \\
\hline $\mathrm{L}$ (crust) & $-0.830^{* *}$ & $-0.775^{* *}$ & $-0.703^{* *}$ & $-0.768^{* *}$ & 1 & & & & & \\
\hline a (crust) & $-0.806^{* *}$ & $-0.769^{* *}$ & $-0.586^{* *}$ & $-0.783^{* *}$ & $0.709^{* *}$ & 1 & & & & \\
\hline $\mathrm{b}$ (crust) & $-0.890^{* *}$ & $-0.815^{* *}$ & $-0.692^{* *}$ & $-0.815^{* *}$ & $0.940^{* *}$ & $0.863^{* *}$ & 1 & & & \\
\hline Batter viscosity & $0.860^{* *}$ & $0.758^{* *}$ & $0.672^{* *}$ & $0.747^{* *}$ & $-0.728^{* *}$ & $-0.806^{* *}$ & $-0.818^{* *}$ & 1 & & \\
\hline Hardness & $-0.793^{* *}$ & $-0.700^{* *}$ & $-0.803^{* *}$ & $-0.769^{* *}$ & $0.675^{* *}$ & $0.472^{* *}$ & $0.680^{* *}$ & $-0.545^{* *}$ & 1 & \\
\hline Springiness & $-0.757^{* *}$ & $-0.716^{* *}$ & $-0.540^{* *}$ & $-0.746^{* *}$ & $0.682^{* *}$ & $0.784^{* *}$ & $0.765^{* *}$ & $-0.711^{* *}$ & $0.557^{* *}$ & 1 \\
\hline
\end{tabular}

${ }^{* *}$ indicate significance at $p<0.01$.

\section{Conclusion}

The incorporation of flaxseed flour (20-40\%) and xanthan gum $(0.8 \%)$ into the formulations of gluten-free layer cakes could be a great improvement for the height, volume symmetry and uniformity index and flaxseed flour supplement. It decreased the hardness of cake and mitigated stale of cake. It increased the $\alpha$-linolenic acid, protein content of cake, batter viscosity, phenolics content and antioxidant activity of gluten-free layer cakes. The presence of flaxseed flour and xanthan gum was desirable to possess antioxidant capacities for potential gluten-free product applications.

\section{References}

[1] Sollid LM, Lundin KEA. Diagnosis and treatment of celiac disease. Muscosal Immunol 2: 3-7, 2009.

[2] Jnawali P, Kumar V, Tanwar B. Celiac disease: Overview and considerations for development of gluten-free foods. Food Science and Human Wellness 5: 169-176, 2016.

[3] Grace-Farfaglia P. Bones of contention: bone mineral density recovery in celiac disease- a systematic review. Nutrients 7 : 33473369, 2015.

[4] Belitz H D, Grosch W and Schieberle P. Cereals and cereal products. In: Food Chemistry $\left(4^{\text {th }}\right)$. Springer-Verlag, Berlin, Heidelberg, Germany, 2009, 670-745.

[5] Capriles VP, Areas JG. Novel approaches in gluten-free breadmaking: interface between food Science, nutrition, and health. Comp Rev Food Sci F 13: 871-890, 2014.

[6] Dhen N, Roman L, Rejeb IB, Martinez MM, Garogouri M, Gomez M. Particle size distribution of soy flour affecting the quality of enriched gluten-free cakes. LWT-Food Sci Technol 66: 179-185, 2016.

[7] Marston K, Khouryieh H, Aramouni F. Effect of heat treatment of sorghum flour on the functional properties of gluten-free bread and cake. LWT-Food Sci Technol 65: 637-644, 2016.

[8] Gularte MA, Hera E, Gomez M, Rosell CM. Effect of different fibers on batter and gluten-free layer cake properties. LWT-Food Sci Technol 48: 209-214, 2012.

[9] Perez CM, Juliano BO. Varietal differences in quality characteristics of rice layer cakes and fermented cakes. Cereal Chem 65: 40-43, 1988.

[10] Mohamed S, Hamid NA. Effects of ingredients on the characteristics of rice cakes, J Sci Food Agric 76: 464-468, 1998.

[11] Johnson FS. Characteristics of muffins containing various levels of waxy rice flour. Cereal Chem 67: 114-118, 1990.

[12] Ibrugger S, Kristensen M, Mikkelsen MS, Astrup A. Flaxseed dietary fiber supplements for suppression of appetite and food intake. Appetite 58: 490-495, 2012.
[13] Hao M, Beta B. Development of Chinese steamed bread enriched in bioactive compounds from barley hull and flaxseed hull extracts. Food Chem 139: 1320-1325, 2012.

[14] Gularte MA, Gomez M, Rosell CM. Impact of legume flours on quality and in vitro digestibility of starch and protein from glutenfree cakes. Food Bioprocess Tech 5: 3142-3150, 2012.

[15] Allais I, Edoura-Gaena RB, Gros JB, Trystram G. Influence of egg type, pressure and mode of incorporation on density and bubble distribution of a lady finger batter. J Food Eng 74: 198-210, 2006.

[16] AACC. Approved methods of the American Association of Cereal Chemists. $10^{\text {th }}$ ed. Methods 44-15A, 02-52, 76-21, 10-90, 10-05. St. Paul, Minnesota, 2000.

[17] Cruz-Romero M, Kelly AL, Kerry JP. Effects of high-pressure and heat treatments on physical and biochemical characteristics of oysters (Crassostrea gigas). Innov Food Sci Emerg 8: 30-38, 2007.

[18] Mathlouthi M. Water content, water activity, water structure and the stability of foodstuffs. Food Control 12: 409-417, 2001.

[19] AOAC. Official Methods of Analysis of the Association of Official Analytical Chemists. 16th ed. Sidney W (eds) Washington D.C., USA, 1998.

[20] Seczyk L, Swieca M, Dziki D, Anders A, Gawlik-Dziki U. Antioxidant, nutritional and functional characteristics of wheat bread enriched with ground flaxseed hulls. Food Chem 214: 32-38, 2017.

[21] Singleton VL, Rossi JA. Colorimetry of total phenolics with phosphomolybdic-phosphotungstics acid reagents. Am J Enol Vitic 16: $144-158,1965$.

[22] Shimada K, Fujikawa K, Yahara K, Nakamura T. Antioxidative properties of xanthan on the antioxidation of soybean oil in cyclodextrin emulsion. J Agric Food Chem 40: 945-948, 1992.

[23] Oyaizu M. Antioxidative activities of browning products of glucosamine fractionated by organic solvent and thin-layer chromatography. Nippon Shokuhin Kogyo Gakkaishi 35: 771-775, 1988.

[24] Sudha ML, Baskaran V, Leelavathi K. Apple pomace as a source of dietary fiber and polyphenols and its effect on the rheological characteristics and cake making. Food Chem 104: 686-692, 2007.

[25] Ashwini A, Jyotsna R, Indrani D. Effect of hydrocolloids and emulsifiers on the rheological, microstructural and quality characteristics of eggless cake. Food Hydrocoll 23: 700-707, 2009

[26] Stauffer CE (1990) Functional additives for bakery foods. AVI, New York, NY; 1990. 69-124.

[27] Garden J. Flaxseed gum: Extraction, characterization, and functionality. PhD Thesis, North Dakota State University, Fargo, ND, USA, 1993.

[28] Marpalle P, Sonawane SK, Arya SS. Effect of flaxseed flour addition on physicochemical and sensory properties of functional bread. LWT-Food Sci Technol 58: 614-619, 2014.

[29] Fustier P, Castaigne F, Turgeon SL, Billiaderis CG. Impact of commercial soft wheat flour streams on dough rheology and quality attributes of cookies. J Food Eng 90: 228-237, 2009.

[30] Rickard SE. Health effects of flaxseed mucilage, lignans. Flax Council of Canada 8: 860, 1989.

[31] Simpoulos AP. Omega-3 fatty acids in wild plants nuts and seeds. Asia Pac J Clin Nutr 11: S163-S173, 2002. 
[32] Chetana R, Sudha ML, Begum K, Pamasarma PR. Nutritional characteristics of linseed/flaxseed (Linum usitatissimum) and its application in muffin making. J Texture Stud 41: 563-578, 2010.

[33] Cabo J, Alonso R, Mata P. Omega-3 fatty acids and blood pressure. Br J Nutr 107: S195-S200, 2012.

[34] Meral R, Sait Dogan I. Quality and antioxidant activity of bread fortified with flaxseed. Ital J Food Sci 25: 51-56, 2013.

[35] Mervat E, Mahmoud KF, Barch GF, Albadway W. Effect of fortification by full fat and defatted flaxseed flour sensory properties of wheat bread and lipid profile laste. Int J Curr Microbiol Appl Sci 4: 581-598, 2015.

[36] Khouryieh H, Aramouni F. Physical and sensory characteristics of cookies prepared with flaxseed flour. J Sci Food Agric 92: 23662372, 2012.

[37] Ramcharitar A, Badrie N, Mattfeldt-Beman M, Matsuo H, Ridley C. Consumer acceptability of muffins with flaxseed (Linum usitatissimum). J Food Sci 70: S504-S507, 2005. 